\title{
The Early Wittgenstein on Living a Good Ethical Life
}

\author{
Jordi Fairhurst ${ }^{1}$ (D)
}

Received: 12 July 2021 / Revised: 3 February 2022 / Accepted: 3 February 2022 /

Published online: 24 February 2022

(c) Springer Nature B.V. 2022

\begin{abstract}
This paper offers a novel interpretation of Wittgenstein's early conception of ethics and the good ethical life. Initially, it critically examines the widespread view according to which Wittgenstein's early conception of ethics and the good ethical life involves having a certain ethical attitude to the world. It points out that this reading incurs in some mistakes and shortcomings, thereby suggesting the need for an alternative reading that avoids and amends these inadequacies. Subsequently, it sets out to offer said reading. Specifically, it is argued that the good ethical life is predicated on a good exercise of the ethical will and solving the riddle of life, both of which demand a certain view of, and not an attitude to, the world. This view is the view of the world sub specie aeterni.
\end{abstract}

Keywords Wittgenstein · Tractatus Logico-Philosophicus · Ethics · Good ethical life $\cdot$ Ethical will $\cdot$ Meaning of life.

\section{Introduction}

For early Wittgenstein's philosophy, ethics undoubtedly played a central role in the Tractatus Logico-Philosophicus ([Wittgenstein 2001]; hereafter, Tractatus). He went as far as stating, in a letter to Von Ficker, that the point of the book is ethical. Despite the overarching importance of ethics, Wittgenstein left us with a small handful of obscure and cryptic propositions about ethics at the end of the Tractatus. These prop-

Jordi Fairhurst

jordi.fairhurst@uib.es; jordi-f@hotmail.com

1 Departamento de Filosofía y Trabajo Social, Universidad de las Islas Baleares, Islas

Baleares, Palma de Mallorca, Spain 
ositions have proven extremely hard to interpret, as evidenced by the multiple ongoing exegetical discussions among Wittgenstein scholars.

In this paper I attempt to shed some light on Wittgenstein's early conception of ethics and the good ethical life in the Tractatus. I begin, in Sect. 2, by outlining Wittgenstein's characterization of ethical value and spelling out its consequences for ethics. Subsequently, in Sect. 3, I examine the widespread view according to which Wittgenstein's early conception of ethics and the good ethical life involves having a certain ethical attitude to the world. Finally, in the last sections, I set out to provide a novel interpretation by examining Wittgenstein's understanding of the ethical will and the riddle of life in the Tractatus.

\section{Ethics in the Tractatus}

In propositions 6.4 and 6.41 Wittgenstein explains that ethical value must lie outside the world. This is due to the incompatible characterization he offers of the world and ethical value (cf. [TLP: 6.4-6.422, 6.4321]). The world is composed of accidental facts: it is the sphere of what happens and is the case. Meanwhile, ethical value is non-accidental: it is the sphere of what is absolutely and necessarily valuable. If ethical value existed in the world it would itself be accidental and, thereby, be of no value.

Wittgenstein, consequently, endorses the fact-value distinction, which he had earlier defended in the Notebooks ([Wittgenstein 2015]; cf. [NB: 5.7.16, 2.8.16, 12.10.16]) and later re-asserted in 'Lecture on ethics' ([Wittgenstein 1965] ccf. [LOE: $5-7,10]$ ) when distinguishing between judgments of relative value (i.e., statements of facts) and judgments of absolute (ethical) value. Accidental facts cannot inherently possess ethical value: they are neither ethically good nor ethically bad.

It may be argued that facts can still be extrinsically good, despite not being intrinsically good. For instance, they may be good for a certain purpose or because they stand in some relation to something. Wittgenstein, unfortunately, also rejects this idea. He explains that ethical goodness is universal and necessary, not relative to accidental and contingent ends which are dependent on personal inclinations [LOE: 5-7]. Ethical goodness is 'the absolute right road': "the road which everybody on seeing it would, with logical necessity, have to go, or be ashamed for not going" [LOE: 7]. The necessity and universality that characterizes ethical goodness (and absolute ethical value in general) cannot be found in, or related to, accidental and contingent facts in the world.

If absolute goodness were intrinsically or extrinsically related to a fact, it 'would be one which everybody, independent of his tastes and inclinations, would necessarily bring about or feel guilty for not bringing about. And I want to say that such a state of affairs is a chimera' [LOE: 7]. Facts are neither intrinsically nor extrinsically valuable, they do not belong to the solution of ethical problems [TLP, 6.4321]. This is exemplified by Wittgenstein's critique of the famous quote from Hamlet: 'Nothing is either good or bad, but thinking makes it so', i.e., things are extrinsically good or bad, not intrinsically good or bad. Against Hamlet, Wittgenstein argues that 'a state of mind, so far as we mean by that a fact which we can describe, is in no ethical sense 
good or bad' [LOE: 6]. Moreover, Wittgenstein went as far as stating that a murder (i.e., unlawful killing) is on the same level as any other event in the world (e.g., the falling of a stone) in order to emphasize the severity of the fact-value distinction [NB: 12.10.16; LOE: 6-7].

Wittgenstein's early views on ethical value entail two important consequences for ethics and moral philosophy. On the one hand, Wittgenstein's fact-value distinction means 'there can be no ethical propositions' [TLP, 6.42]. The picture of language propounded or assumed in the Tractatus imposes two conditions for the sense of pictures (i.e., thoughts and propositions). First, they must be logical pictures. Namely, they must share their logical form with the reality they depict [TLP, 2.181-2.19, 3, 4.03]. Second, they must depict (or represent) the existence and non-existence of states of affairs [TLP, 2.221-2.222, 4.01, 4.023, 4.1, 4.2]. Given that ethical value must lie outside of the world, there are no ethical states of affairs to be represented. Accordingly, there are no senseful or meaningful ethical propositions. 'Propositions can express nothing that is higher' ([TLP, 6.42]; for similar pronouncements see [NB, 30.7.16; LOE, 7; Waissman, 1979, 68-69]).

On the other hand, Wittgenstein's fact-value distinction means that the objective mark of ethical goodness or badness 'cannot be a physical one', i.e., something which can be described by meaningful propositions, 'but only a metaphysical one, a transcendental one' [NB, 30.7.16]. Ultimately, there are no facts or propositions 'which, in any absolute sense, are sublime, important, or trivial' [LOE, 6]. 'All the facts described would, as it were, stand on the same level and in the same way all propositions stand on the same level' [LOE, 6]: they are ethically valueless [TLP, 6.4-6.421]. This does not mean that facts are ethically irrelevant. They can contribute to setting ethical problems ([TLP: 6.4321] see Sect. 4.2 for an example regarding how facts may contribute to setting ethical problems). However, they cannot contribute to their solution. The objective mark of ethical goodness and a good ethical life cannot be something described in senseful propositions. 'This mark cannot be a physical one but only a metaphysical one, a transcendental one' [NB, 30.7.16].

The lack of meaningful ethical propositions and the non-existence of ethical value in the world has often been interpreted by Wittgenstein scholars as involving a rejection of traditional philosophical ethics. ${ }^{1}$ Namely, Wittgenstein, in the Tractatus, does not intend to outline a philosophical ethical theory that, through the use of ethical propositions, provides an ethical doctrine with certain imperatives or ethical laws that

\footnotetext{
${ }^{1}$ A reviewer rightly points out that Wittgenstein early ethical views entail a rejection of many things which we commonly associate with ethics. For instance, moral talk is deemed nonsensical or senseless, and human behavior is deemed a valueless fact. A detailed critical investigation of the validity of Wittgenstein's early ethical views exceeds the aim and scope of this paper, which is primarily exegetical. Nevertheless, it is noteworthy that Wittgenstein himself refrained from propounding these views after 1931 (see [Kuusela, 2018; Christensen, 2011; Glock, 2015] for a detailed explanation of the development of Wittgenstein's moral philosophy). For the later Wittgenstein, 'the ethical shows itself no longer in the attitudes of a lonely self, but in social patterns of action' [Glock, 2015, 109]. So, 'the Later Wittgenstein no longer seeks to explain ethics in terms of the problem of the relation of the will to reality" or "explaining the possibility of ethical value in a wholesale manner' [Kuusela, 2018, 52-53]. Instead, he seeks to clarify the nature of ethics, particular ethical concepts, and practices via piecemeal grammatical investigations of the uses of relevant locutions. Albeit he does maintain his critical stance against the postulation of moral entities, such as moral properties (see [Richter, 2018; Kuusela, Forthcoming; Fairhurst, 2021b]).
} 
regulate our behaviour and specify what is right and wrong conduct. ${ }^{2}$ When faced by an ethical law of the form 'Thou shalt...' one can simply contend 'And what if I do not do it' [TLP 6.422] (cf. [NB: 30.7.16; LOE: 7, 10; Waissman, 1979, 117-118; CV: 4/MS 107192 c: 10.11.1929]). The rejection of traditional philosophical ethics coincides with Wittgenstein's rejection of philosophical and metaphysical theories (cf. [TLP: 3.324, 4.112, 6.53; NB: 2.12.16]). However, given that Wittgenstein discards traditional ethical theories, what is the Tractarian ethics about?

Following his initial characterization of ethics, Wittgenstein [TLP 6.422] explains that ethics has to do with ethical punishment, which must be something unpleasant, and ethical reward, which must be something pleasant. These terms are not to be understood in their usual sense, i.e., as certain happenings in the world that are consequences of our actions. Conversely, ethical reward and ethical punishment 'must reside in the action itself' [TLP: 6.422] and are later identified as ethical happiness and ethical unhappiness respectively (cf. [TLP: 6.422, 6.43]).

Ethics, then, is concerned with being ethically good, receiving ethical reward (i.e., happiness) and living a good ethical life (cf. [TLP: 6.422-6.45]). However, given Wittgenstein's fact-value distinction, being ethically good and acting correctly are not to be identified with certain facts or happenings in the world. Namely, the mark of ethical goodness and ethical badness cannot be a physical mark, as it would be of no value [TLP: 6.41] (cf. [NB 30.7.16]). This raises some interesting and puzzling questions: how should ethical actions be understood? What is the mark of ethical goodness and ethical badness? And, finally, what is needed for a good ethical life?

\section{An Attitude to the World}

According to a widespread reading, being ethically good and living a good ethical life involve having a certain ethical attitude to the world. Wittgenstein scholars have mainly characterized this ethical attitude in two different ways. ${ }^{3}$ First, Cavalier [1980, 159-160, 165-166, 173-175, 187-195], Worthington [1981, 486-489], Edwards [1982, 26, 46-47, 57, 67-68], Thomas [1999, 196], Diamond [2000, 153155], Churchill [2009, 113-114, 121-123], Hughes [2009, 52, 56-58], Appelqvist

\footnotetext{
${ }^{2}$ Wittgenstein, in his meetings with the Vienna Circle between 1929 and 1931, stated: 'if I could explain the essence of the ethical only by means of a theory, then what is ethical would be of no value whatsoever. [...] For me a theory is without value. A theory gives me nothing' [Waissman, 1979, 117]. Morris [2008, 326] fails to acknowledge these remarks and (mis)interprets Wittgenstein as advancing a particular kind of normative ethics with ethical imperatives.

${ }^{3}$ This section critically examines some inadequate aspects common to some existing proposals via short characterizations that bring out the problematic features they share. My brief characterizations do not flesh out the subtleties of these proposals, which are far too intricate as to discuss in detail here. My aim here, however, is not to discuss all the intricacies of these proposals, but rather draw attention to certain shortcomings that need to be amended. Accordingly, the criticisms I will offer do not undermine the entirety of the proposals I discuss. A lot of the intricacies of these proposals are of great interest for the present investigation and contribute to a better understanding of Wittgenstein's early moral philosophy. For instance, the ideas I develop in Sect. 4.2 are sympathetic towards the wide-spread interpretation that, for Wittgenstein, being ethically good amounts to living in acceptance or agreement with the facts of the world.
} 
[2013, 47-49, 51, 53] and Kuusela [2018, 45-51] hold that the correct ethical attitude is living in acceptance or agreement with the facts of the world, whatever they may be.

Hughes, Appelqvist and Churchill add that this acceptance is the result of 'doing the will of God', i.e., living 'in agreement with that alien will, on which I am dependent' [NB, 8.7.16]. (Kuusela, [2018, 46] also quotes this entry of the Notebooks, but suggests that it is no more than a simile). Appelqvist and Hughes, together with Thomas, further suggest that we can only live in acceptance with the world '-and so in a certain sense master it- by renouncing any influence on happenings' [NB, 11.6.16]. This renunciation entrains a submission to the will or (power) of God. Kuusela, in turn, is critical of this renunciation. He explains that renouncing influence on the world 'is morally questionable insofar as it may lead, for example, to a passive acceptance of injustices' ([Kuusela, 2018, 49]; see note 23). Instead, ethics is concerned with 'a particular mode of our experience of the world [...] as valuable and meaningful' [Kuusela, 2018, 47]. This experience is that of living in harmony with reality by adopting the attitude that, whatever one wills, the outcome must be accepted.

Second, Tejedor [2013, 63, 73-79] and Harcourt ([Forthcoming, 1-5, 8-9]; see Rudebush and Berg [1979, 152-153] for similar pronouncements) explain that the correct ethical attitude amounts to having conceptual clarity. The successful application of Wittgenstein's philosophical method, namely the correct method in philosophy described in 6.53, results in achieving conceptual clarity and, therefore, being ethically good and living a good ethical life.

Tejedor $[2013,74]$ holds that having a religious or ethical attitude to the world involves being in a state of conceptual clarity. Namely, it is being clear about certain formal concepts, having certain practical abilities honed in and thus being disposed to use signs so as to reflect the fundamental contingency of facts. This, in turn, involves treating ourselves (i.e., human beings) as facts on a par, with respect to their contingency, with all other facts in the world [Tejedor, 2013, 74]. On this interpretation, the Tractatus has an ethical purpose, not because it contains the TLP 6.4ff, 'but because the book -as a whole- enables us to hone in our mastery of certain formal concepts' ([Tejedor, 2013, 78]; for a study on the ethical point of the Tractatus see Fairhurst [2021a]). Meanwhile, Harcourt argues that philosophical confusion is a mark of personal badness and that only the correct method of philosophy remedies this confusion. 'It follows that philosophy, when practiced successfully,' results in conceptual clarity and thus 'makes one better' [Harcourt, Forthcoming, 1]. Like Tejedor, on this interpretation the Tractatus has an ethical purpose, not because it contains the TLP 6.4ff, but because the whole book makes manifest the attitude of the happy person. In like manner, Rudebush and Berg [1979, 153] suggest that Wittgenstein saw the correct method of philosophy as a machine that allowed him to overcome his lack of decency.

Additionally, Mulhall [2007, 232-233, 236, 243-245] seems to offer a middle ground approach between these two distinct ways of characterizing the correct ethical attitude. Mulhall [2007, 245] explains that the "successful application of this philosophical method will constitute an expression of the orientation of the happy person - a capacity to accept the world and its limits, to overcome any apprehension 
of oneself as limited, constrained or punished thereby". By contrast, anyone who runs up against the limits of language and, by extension, the world is an inhabitant of the world of the unhappy because they experience everything that happens as an imposition. ${ }^{4}$

Despite the widespread popularity of this reading, there are two pressing issues that threaten to undermine the idea that, for Wittgenstein, being ethically good and living a good ethical life involve having an attitude to the world..$^{5}$

First, there is a lack of textual evidence in the Tractatus to support the claim that being ethically good and living a good ethical life involves having a certain ethical attitude to the world. Wittgenstein does not use nor discuss the notion 'Attitude' or 'Stellungnahme' in the Tractatus when speaking about ethics. The only occurrence of these notions in Wittgenstein's early work on ethics is to be found in an entry dated 4.11.16 of the Notebooks, where Wittgenstein says: 'the will is an attitude of the subject to the world' [NB, 4.11.16]. Thus, this widespread reading appears to have originated from Wittgenstein's Notebooks. More specifically, it seems that interpreters (implicitly or explicitly) invoked NB 4.11.16 to make sense of Wittgenstein's scarce remarks on the ethical will in 6.423-6.43 of the Tractatus and, by extension, Wittgenstein's early ethics. Subsequently, other interpreters took for granted that Wittgenstein's ethics involves having a certain attitude to the world and discussed what this ethical attitude might be.

But does NB 4.11.16 suffice to substantiate the claim that ethics in the Tractatus primarily revolves around having an ethical attitude to the world? In 4.11.16 Wittgenstein engages in a thoughtful discussion about the will. Throughout this entry he studies the connection between our will and the actions that constitute its fulfilment, the differences between wishing and willing and so on. Leaving aside the intricacies of his remarks, it is important to take note that Wittgenstein is studying the will as a phenomenon in the world. This is evidenced by the following passages:

It is clear, so to speak, that we need a foothold for the will in the world. $[\ldots]$

\footnotetext{
${ }^{4}$ Although I do not endorse Tejedor's, Harcourt's and Mulhall's views on Wittgenstein's early conception of ethics, I do agree that the correct method of philosophy can offer important contributions to the ethical task of achieving a good ethical life. Specifically, the correct method of philosophy can serve as a helpful tool which contributes to the undergoing of the necessary ethical changes required for a good ethical life (see [Richter, 1996, 249; Christensen, 2011; Kuusela, 2018, 50-51; Fairhurst, 2021a]). For instance, the correct philosophical method can help on develop 'a capacity to accept the world and its limits, to overcome any apprehension of oneself as limited, constrained or punished thereby' [Mulhall, 2007, 245]. Ultimately, however, I believe that displaying conceptual clarity in language-use is not a necessary requirement for a good ethical life. This proposed interpretation seems to go against Wittgenstein's factvalue distinction, since the mark of ethical goodness (i.e., displaying conceptual clarity in our languageuse) and the mark of ethical badness (i.e., displaying conceptual confusion in our language-use) are both understood as physical marks in the world. Against 6.41 and 6.4321, certain states of affairs, for instance the utterance of a senseful proposition, are regarded as ethically valuable and the solution to ethical problems. In other words: it is assumed that certain happenings and propositions are more valuable than others. In doing so, it fails to acknowledge that displaying conceptual clarity in language-use is no more than another happening in the work and, thus, cannot be ethically valuable or the objective mark of the ethical.

5 These issues may also affect those interpreters (e.g., [Kelly, 1995, 575]) who claim that Wittgenstein does not detail what this ethical attitude is.
} 
The act of the will is not the cause of the action but is the action itself.

[...]

If the will has to have an object in the world, the object can be the intended action itself.

And the will does have to have an object.

Otherwise we should have no foothold and could not know what we willed.

And could not will different things.

[...]

My will fastens on to the world somewhere, and does not fasten on to other things. [NB, 4.11.16]

As Wittgenstein later explains in TLP 6.423, the will as a phenomenon (or phenomenal will) is of interest only to psychology. The reason why it is not of interest to ethics is partly rooted in Wittgenstein's fact-value distinction. As explained in Sect. 2, the objective mark of ethical goodness or badness 'cannot be a physical one', i.e., something which can be described by meaningful propositions, 'but only a metaphysical one, a transcendental one' [NB, 30.7.16]. Thus, the will, understood as a phenomenon in the world, cannot be the objective mark of the ethical and, by extension, is not of interest to ethics.

Ethics is interested in the ethical will, i.e., the will as the subject of ethical attributes [TLP, 6.423]. ${ }^{6}$ The good and bad exercise of the ethical will does not have a foothold in the world. Namely, the ethical will does not fasten onto to the world somewhere to change or alter the facts that occur, i.e., things which can be expressed in language [TLP, 6.43]. Instead, the good and bad exercises of the ethical will 'can alter only the limits of the world' ([TLP, 6.43]; see Sect. 4.2 for an explanation).

It follows from the above that the ethical will is not the will as a phenomenon [TLP, 6.423]. Thus, it seems misguided to resort to NB 4.11.16 to provide an interpretation of the ethical will in the Tractatus and suggest that ethics is primarily concerned with having an ethical attitude to the world. Wittgenstein's remarks throughout 4.11.16 focus solely on the will as a phenomenon. He shows no interest in ethical issues and refrains from revisiting his earlier ethical discussions surrounding the will. The characterization of the phenomenal will as a certain attitude does not contribute to, nor deepen, our understanding of the ethical will in 6.423 nor of the ethics in the Tractatus. Furthermore, there is no textual evidence to settle whether Wittgenstein still conceived the phenomenal will as an attitude in the Tractatus or if he had abandoned this idea at some point between 1916 and the publication of the Tractatus.

Second, various advocates (see e.g., [Cavalier, 1980, 159-160, 165-166, 173175, 187-195; Edwards, 1982, 26, 46-47, 57, 67-68; McGuiness, 2002, 141; Morris 2008, 324; Harcourt, Forthcoming, 1-5]) of this widespread reading implicitly or

\footnotetext{
${ }^{6}$ Wittgenstein did not explicitly draw this distinction in his Notebooks, albeit I believe that there are certain entries where he does hint towards it and implicitly assumes it (see e.g., [NB 5.7.16, 21.7.16, 29.7.16, 5.8.16]). The lack of an explicit formulation of this distinction comes as no surprise given that at various points Wittgenstein (see e.g., [NB 8.7.16]) admits that he is unclear about the topic of the will and that he is 'still making crude mistakes! No doubt of that!' [NB 29.7.16]. Furthermore, even if Wittgenstein did not assume this distinction, what is important for our purposes here is that NB 4.11.16 discusses the will as a phenomenon.
} 
explicitly characterize this ethical attitude in psychological terms as a mental fact, a state of mind or an emotive response. For instance, McGuinness holds that this ethical attitude is an emotive response (i.e., a mental fact or state of mind) to the world: "the way what is possible feels to us" ([Morris, 2008, 324] see [Tejedor, 2013, 56, 74-75] for a critical discussion). Meanwhile, Harcourt's interpretation suggests that the correct ethical attitude is conceptual clarity, a mental fact or state of mind which is manifested in our ability to think and use propositions correctly. ${ }^{7}$ In other words: "philosophical confusion is a mark of personal badness" and "philosophy when practiced successfully makes one better" by remedying "confusion" and attaining conceptual clarity [Harcourt, Forthcoming, 2].

However, as explained in Sect. 2, the objective mark of ethical goodness or badness 'cannot be a physical one', i.e., a fact which can be described by meaningful propositions, 'but only a metaphysical one, a transcendental one' [NB, 30.7.16]. Likewise, a mental fact or 'a state of mind, so far as we mean by that a fact which we can describe, is in no ethical sense good or bad' [LOE, 6]. Emotive responses to the world and conceptual clarity (understood as a mental fact or state of mind which is manifested in our ability to think and use propositions correctly) are just describable happenings in the world which are in no ethical sense good or bad. 'All the facts described would, as it were, stand on the same level' [LOE, 6]: they are ethically valueless [TLP, 6.4-6.421]. Thus, it is misguided to claim that the mark of the ethical is a physical or psychological one. Attitudes, insofar as they are facts that can be described by senseful propositions, cannot be the objective mark of the ethical.

Some Wittgenstein scholars (see e.g., [Kuusela, 2018, 44-51; Diamond, 2000, 153-155]) rightfully refrain from characterizing this ethical attitude in psychological terms. Unfortunately, in other instances the use of the notion 'attitude' seems to remain troublesome even when we acknowledge that it is not a (mental) fact. This is because it is often implicitly conflated with its ordinary psychological meaning, thereby leading to unwanted confusions about Wittgenstein's ethics. These kinds of confusions are exemplified by the work of those interpreters (see e.g., [Hughes, 2009, 57-58; Churchill, 2009, 121]) who remain ambiguous on this topic by both assuming that an ethical attitude is a mental state or an experience and, simultaneously, repudiating this claim at other ventures of their work. For instance, Hughes [2009, 57] holds that the correct ethical attitude and ethical happiness cannot "reside in the fact that on has a happy optimistic disposition", since this "would be merely features of the world with which we must come to terms". However, shortly thereafter Hughes seemingly characterizes the correct ethical attitude and ethical happiness in psychological terms. More specifically, he explains that to be happy we must be "free from fear and hope"

\footnotetext{
7 Tejedor [2013, 75] sets out to avoid the claim that an ethical attitude is a mental fact by arguing that it is not an emotive response, but a disposition to use signs correctly. Although she rightfully demonstrates that dispositions are not emotive responses, it is unclear why we should accept that dispositions cannot be mental facts. A disposition is a condition or state that provides the possibility for some further specific state or behavior. Given that conceptual clarity may be understood as a describable mental state, a disposition to use signs correctly may be conceived a dispositional mental state which is exhibited in our linguistic behavior and how we think. Accordingly, a disposition to use signs in a certain way could be just another describable fact in the world. Further arguments are required to show that this ethical-religious dispositional attitude is not a mental fact.
} 
since "both of these propel the subject into the future with all its uncertainties" and "destroy our present happiness through anxiety" [Hughes, 2009, 57-58].

\section{A Good Ethical Life}

I believe the combination of the two issues described in Sect. 3 (i.e., the troubles and confusions implicit in the use of the notion 'ethical attitude' together with the lack of textual evidence in Wittgenstein's early work on ethics) indicate that it is best to refrain from speaking about an ethical attitude, in favor of offering an alternative conception of Wittgenstein's ethics which helps us avoid these misunderstandings and shortcomings. My aim in this paper is to offer this alternative interpretation by defending that being ethically good and living a good ethical life demands a certain view of the world, instead of a certain attitude to the world. ${ }^{8}$ Initially, I present textual evidence favoring this interpretation. Subsequently, I show how this proposal avoids claiming that the mark of the ethical is a physical one. Finally, I outline how this view of the world contributes to Wittgenstein's early conception of ethics and the good ethical life.

\subsection{Viewing the World sub specie aeterni}

The notions 'seeing' and 'viewing' recurringly figure among Wittgenstein's terminology when discussing ethics in the Tractatus. For instance, in proposition 6.45 he speaks about the view of the world sub specie aeterni. Other examples of Wittgenstein's use of the notions 'seeing' and 'viewing' can be found in: 6.4311 when reintroducing the analogy of the visual field he had discussed when examining the metaphysical subject (cf. [TLP, 5.632-5.641]), 6.521 when discussing the solution of the problem of life and, finally, 6.522 when examining the mystical. ${ }^{9}$ Likewise, he often favored these notions when speaking about ethics in the Notebooks (see e.g., [NB, 11.6.16, 29.7.16, 4.8.16, 5.8.16, 7.10.16, 20.10.16]). I believe Wittgenstein's preference for notions 'seeing' and 'viewing' is not merely arbitrary and accidental, but indicative of his conception of ethics and the good ethical life. This may be attested by further examining his earlier discussions of ethics and the good ethical life.

\footnotetext{
${ }^{8}$ John [1988, 498-508] and Cahill [2004; 2011, 42-45, 54-58] provide another possible alternative reading which claims that the living a good ethical life requires reawakening a sense of wonder. The main issue with their proposal is that Wittgenstein neither speaks about a sense of wonder nor uses the notion 'wonder' in the Notebooks, Prototractatus [Wittgenstein 1997] or Tractatus. Furthermore, the textual evidence adduced by John and Cahill is self-defeating. They primarily resort to Wittgenstein's 'Lecture on Ethics', where he speaks about the experience of wonderment at the existence of the world. Wittgenstein [LOE, 10], however, acknowledges that this experience must surely be a fact, it takes place then and there, lasts a certain definite time and consequently is describable. 'It is the paradox that an experience, a fact, should seem to have supernatural value' [LOE, 10].

9 Wittgenstein uses the word 'Anschauung' in 6.45, which has been translated as 'contemplation' by Ogden and 'view' by Pears and McGuinness. I will favor the latter given that the implication of Wittgenstein's remarks suggests that by 'Anschauung' he means an (active) perspective or way of seeing (see [Mulhall, 2007, 238-239; Atkinson, 2009, 68-69,74-75, 113] for a defense).
} 
Between 1914 and 1916 Wittgenstein wrote a series of coded remarks on the left-hand pages of his wartime diaries known as Geheime Tagebücher [Wittgenstein 1991] - leaving the right-hand pages for his philosophical reflections known as the Notebooks. Interestingly, on the 6th of May 1916, he wrote: 'In constant danger of my life. . From time to time I despair. This is the fault of a wrong view of life' [Wittgenstein 2000, MS 103-09v; Klagge's, 2011, 10 translation]. He spoke about the importance of viewing life correctly again on the 7th of May 1916 (see [MS 103-10v]) and then equated sin with a false or incorrect view of life on the 29th of July [GT, 74; MS $103-19 v$ ] — the same day he enquires about the nature of seeing in NB 29.7.16. Both entries suggest that living a good ethical life is not accomplished through acting in a certain way or having a certain attitude. Conversely, we must learn to see and view the world and life correctly. Only then we will achieve happiness and avoid sin.

This idea would subsequently make its way into the Notebooks in an entry dated 7.10.16. ${ }^{10}$ There Wittgenstein re-asserted and better explained the ethical (and aesthetical) importance of viewing the world correctly. More specifically, he explains that 'the work of art is the object seen sub specie aeternitatis; and the good life is the world seen sub specie aeternitatis' [NB, 7.10.16; cf. TLP, 6.45]. In other words: living a good ethical life is not accomplished through acting in a certain way or having a certain attitude. Conversely, we must learn to see and view the world correctly: we must see it sub specie aeternitatis. These remarks would finally make their way into the $6.4 \mathrm{~s}$ of the Tractatus. There, once more, Wittgenstein would stress and expound on the ethical importance of viewing the world correctly, i.e., sub specie aeterni [TLP, 6.45], and how it contributes to having a good exercise of the ethical will, solving the riddle of life and, by extension, achieving a good ethical life.

Unlike some instances of the ethical attitude discussed in Sect. 3, the view of the world sub specie aeterni is not a fact nor happening in the world. According to Wittgenstein, seeing or viewing the world sub specie aeterni means viewing the world under the aspect of eternity. Eternity is understood not as infinite temporal duration, but as timelessness belonging to those who live in the present [TLP, 6.4311]. ${ }^{11}$ Adopting this view of the world, then, requires situating ourselves outside space and time through living in the present, i.e., in timelessness (cf. [TLP, 6.4312, 6.45]). In other words: only by living in timelessness can we, thereby, view the world sub specie

\footnotetext{
10 Wittgenstein's remarks in NB 7.10 .16 are prefigured by earlier entries in the Notebooks where he focused on the connection between the purpose or meaning of life and, on the other hand, seeing or viewing the world in a certain way. A non-exhaustive list of examples includes, first, NB 11.6.16 where Wittgenstein introduces the analogy of the eye when discussing ethics and the purpose of life. (Wittgenstein would further explore the analogy of the eye in relation to ethics and the metaphysical subject in NB 4.8.16, 12.8.16 and 20.10.16.). Second, NB 8.7.16 where Wittgenstein examined the connection between God and the meaning of life. There he explains that 'to believe in God means to understand the question about the meaning of life' [NB, 8.7.16]. In turn, believing in God means to "see that the facts of the world are not the end of the matter" and "see that life has a meaning" ([NB, 8.7.16]; my emphasis). Unfortunately, at this point of the Notebooks it remains unclear what this view of the world involves. And, finally, NB 29.7.16 where Wittgenstein enquired about the nature of seeing when discussing ethical happiness and unhappiness, and the good and bad exercise of the (ethical) will.

11 Wittgenstein is implicitly distinguishing between the 'present' as it is ordinarily understood, i.e., a certain instance within time that is found between the past and the future, from the 'present' associated to the view of the world sub specie aeterni, which he characterizes as the timelessness pertaining to eternity.
} 
aeterni from outside space and time. The usual way of looking at things sees objects in space and time from the midst of them. Conversely, the view of the world sub specie aeterni sees the world together with space and time from outside [NB, 7.10.16]. So, contrary to the ethical attitude discussed in Sect. 3, the view of the world sub specie aeterni is outside space and time. It is not a happening in the world that can be meaningfully described with senseful propositions. We can describe what is in our visual field, but we cannot describe the eye or the shape of our visual field (cf. [TLP, 5.633-5.641].

Throughout the remainder of this paper, I set out to defend that it is this view of the world which is central to Wittgenstein's ethics in the Tractatus. More specifically, I explain that the good ethical life is predicated on a good exercise of the ethical will (see Sect. 4.2 and 4.3) and solving the riddle of life (see Sect. 4.4), both of which demand viewing the world sub specie aeterni. I believe that the basis of this proposed interpretation is both the textual evidence available to us and, on the other hand, its characterization of the objective mark of the ethical (i.e., the view of the world sub specie aeterni) as a metaphysical or transcendental one, thereby abiding by Wittgenstein's fact-value distinction. So, counter to those interpreters who characterize the correct ethical attitude as a physical mark in the world (e.g., a mental fact), I offer a proposal that avoids the paradoxical appeal to ethical (mental) facts. Meanwhile, with regards to those interpreters who do not characterize the correct ethical attitude as a mental fact, I offer a proposal with seemingly better textual evidence. Finally, against those interpreters who remain ambiguous on this topic by both assuming that an ethical attitude is a mental state or an experience and, simultaneously, repudiating this claim at other ventures of their work, I offer an interpretation that avoids some of the confusions that stem from invoking the notion 'attitude'.

\subsection{The Ethical Will}

According to Wittgenstein, ethics is concerned with being ethically good, receiving ethical reward (i.e., happiness) and living a good, meaningful and ethical life. However, as a consequence of the fact-value distinction, ethical actions are not to be understood as mental (e.g., attitudes) or physical actions that occur in the world.

Many Wittgenstein scholars (e.g. [Rudebush \& Berg, 1979, 152-153; Cavalier, 1980; Diamond, 2000, 154, 166-168; Kremmer, 2001, 58; Mulhall, 2007, 232-233, 236, 243-245; Hughes, 2009, 52; Tejedor, 2013, 63, 73-79; Harcourt, Forthcoming, $1-5,8-9])$ fail to spell out the consequences of Wittgenstein's fact-value distinction and, therefore, have wrongly assumed that Wittgenstein's ethics has implications for our actions and conduct in the world. The clearest example is to be found in the work of Rudebush and Berg, Mulhall, Tejedor and Harcourt, who claim that being ethically good amounts to a 'disposition to use signs in a way that demonstrates one's conceptual clarity' [Tejedor, 2013, 55]. This reading goes against Wittgenstein's fact-value distinction, since the mark of ethical goodness (i.e., conceptual clarity) and the mark of ethical badness (conceptual confusion) are both understood as physical marks in the world. Against 6.41 and 6.4321, certain states of affairs, for instance the utterance of a senseful proposition, are regarded as ethically valuable and the solution to ethical problems. 
Following Wittgenstein's discussion on the topic of ethical punishment and ethical reward, Wittgenstein focuses on the will in 6.423 and 6.43. There he distinguishes between the phenomenal will and the ethical will. ${ }^{12}$ The phenomenal will is conceived as a certain wish or desire (i.e. a mental state) that is of interest only to psychology and not ethics, insofar as it a fact that cannot be the mark of the ethical.

The ethical will, meanwhile, is the subject of ethical attributes and the main ethical action of Wittgenstein's ethics in the Tractatus. Contrary to the phenomenal will, the ethical will does not have a physical mark in the world - hence 'it is impossible to speak about' it [TLP: 6.43]. The ethical will deals with the world as a limited whole together with space and time, instead of encountering objects in space and time from the midst of them - as is the case with the phenomenal will. Thus, instead of altering facts in the world, the good and bad exercise of the ethical will alters the limits of the world, making it wax and wane as a whole, so that it becomes altogether different. But what is the good and bad exercise of the will? In what way does it alter the limits of the world? And how does it allow us to achieve ethical reward (i.e., ethical happiness) and, thereby, live a good ethical life?

Ordinarily, we express preference for certain facts over others and we attempt to alter the happenings in the world in order to attain those facts we regard as valuable. The problem arises when fate does not unfold as we had wished or desired and we are left feeling unhappy. How can we overcome this predicament? How can we control fate and alter the world in order to achieve happiness and avoid unhappiness? The solution to this predicament is not to be found in a certain physical or mental action. Conversely, it is to be found in the good exercise of the ethical will.

The good exercise of the ethical will demands viewing the world sub specie aeter$n i{ }^{13}$ In viewing the world under the aspect of eternity we are able to feel the world as a limited whole and alter its limits [TLP: 6.45]. ${ }^{14}$ On the one hand, from this view we see that 'no part of the world is privileged or preferred to another' [Hughes, 2009,

\footnotetext{
${ }^{12}$ Wittgenstein [Waissman, 1979, 92-93], in his meetings with the Vienna Circle, offers a similar distinction to explain the double meaning of ethical expressions (e.g., will, good, bad, etcetera). He distinguishes between their psychological sense, e.g. 'He is a good tennis player', and their non-psychological or ethical sense-a distinction used in the Tractatus (cf. [TLP: 5.641]) to differentiate the human being from the metaphysical subject. Wittgenstein [LOE: 5] later reformulated this distinction in terms of relative value/ sense and absolute value/sense.

${ }^{13}$ It is important to introduce two clarifications. First, the ethical self that has a good exercise of the ethical will and views the world sub specie aeterni must also be situated outside space and time. Namely, the ethical self cannot be a part of the world. It must be a limit of the world (like ethics). Here I will endorse an interpretation I have offered elsewhere ([Fairhurst 2019]; cf. [TLP, 5.632-5.641]; see [Appelqvist, 2013, 48 and Kuusela 2018, 45] for similar pronouncements), according to which the ethical subject is conceived as the metaphysical subject discussed in the $5.6 \mathrm{~s}$ of the Tractatus. Contrary the human being, the metaphysical subject does not belong to the world. It resides outside space and time. It is this metaphysical subject that is the ethical subject, the bearer of the ethical. Second, here I do not intend to make an identity claim between willing and seeing. Instead, what I intend to explain is that the way in which the good exercise of the ethical will alters the limits of the world demands viewing the world sub specie aeterni. In other words: to accomplish a good ethical will and alter the limits of the world correctly we must adopt a certain way of seeing the world.

${ }^{14}$ Note this feeling is not a physical/psychological feeling which can be described with meaningful propositions. By contrast, the feeling that the world is a limited whole is a 'mystical feeling' ([TLP, 6.45], my emphasis), which cannot be put into words, rather it shows itself or makes itself manifest (cf. [TLP, $6.522])$.
} 
57]. In other words: through viewing the world sub specie aeterni, we are able to feel the word as a whole and see that no part of the word is more ethically valuable than another. The occurrence of one fact instead of another is ethically irrelevant because ethical value does not lie in the world [TLP: 6.4-6.421].

On the other hand, in adopting the standpoint of eternity and seeing the world as a limited whole we are able to see the connection between the phenomenal will and the world and its ethical implications. More specifically, from this view we see that there is no causal or logical necessitating relation between the phenomenal will and the world. Namely, the world is independent of the phenomenal will ([TLP, 6.3736.374]; cf. [TLP, 2.061-2.062; NB, 11.6.16]). ${ }^{15}$ 'It is hard to see how the relation between intention and action could be a logical one, especially given the obvious empirical fact that our intentions can be thwarted in all sorts of ways' [Teichmann, $2015,50] .^{16}$

However, rejecting a relation of logical necessity between the phenomenal will and the happenings that constitute its fulfilment does not encompass the claim that it impossible for our will to affect changes in the world. 'Just as the only necessity that exists is logical necessity, so too the only impossibility that exists is logical impossibility' [TLP, 6.375]. Wittgenstein offers an example of logical impossibility in TLP 6.3751: 'For two colours, e.g. to be at one place in the visual field, is impossible, logically impossible, for it is excluded by the logical structure of colour'. Accordingly, it is contradictory to state 'Two colors are at one place in visual field'. This does not seem to hold for the relation between the phenomenal will and the world.

Just as it is an obvious empirical fact that our phenomenal will can be thwarted in all sorts of ways, so too it is an obvious empirical fact that our phenomenal will sometimes results in certain changes in the world and is fulfilled by certain happenings. For instance, when I phenomenally will my arm to raise so I can reach for an object in my shelves, this generally (albeit not necessarily) results in a change in the world: I raise my arm to reach for the object. Thus, for me to phenomenally will suchand-such and for such-and-such to occur in the world is not logical impossible (nor logically necessary) and is not excluded by the logical structure of the phenomenal will of the world. Likewise, the proposition 'If I willed such-and-such, then suchand-such will occur' does not result in a contradiction. The logical product of these two elementary propositions (i.e., 'I will such-and-such' and 'Such-and-such will occur') cannot not result in a contradiction, i.e., logical impossibility, nor a tautology, i.e., logical necessity (cf. [TLP, 6.3751]). ${ }^{17}$

\footnotetext{
${ }^{15}$ In 6.373-6.374 Wittgenstein discusses the phenomenal will, not the ethical will. Overlooking this difference can contribute to an inadequate exegesis of Wittgenstein's ethics, as is the case for Kelly [1995, 572] and Morris [2008, 323-324].

${ }^{16}$ Wittgenstein's views on the relation between the phenomenal will and the world ought to come as no surprise, since he had earlier explained that all states of affairs are independent of one another: from the existence of one state of affairs it is impossible to infer the existence of another [TLP 2.061-2.062]. Given that our phenomenal will and the event in the world that constitutes its fulfillment are different states of affairs it is impossible to infer the latter from the former.

17 Note Wittgenstein states that there is 'no logical connection between the will and the world' [TLP, 6.374]. Hence Wittgenstein does not only reject the connection of logical necessity, but any logical connection, such as logical impossibility. Even though some contingent physical connections may be unlikely, they are neither logically impossible nor logically necessary.
} 
So, although there is no logical connection (e.g., necessity or impossibility) between the phenomenal will and the world, it is assumed that there is a supposed physical contingent connection between them [TLP, 6.374]. The issue lies in that this relation 'is surely not something that we could will' [TLP, 6.374]: we cannot necessitate its happening. Instead, the fulfillment of our phenomenal will is ultimately a 'favour granted by fate, so to speak' [TLP, 6.373]. 'It seems as if all I can do is hope that' the happenings that constitute the fulfilment of our phenomenal will 'occur' [Teichmann, 2015, 50]. In other words: although there are certain probabilities that our phenomenal will may effect changes in the world (i.e., that the happenings that constitute its fulfilment may occur), there is no certainty or indubitability that these happenings will occur. You cannot affect these probabilities, rather you assign them on the basis of incomplete knowledge (see [Teichmann, 2015, 50]; cf. [TLP, 6.374]).

Viewing the world sub specie aeterni allows us to situate ourselves outside space and time (cf. [TLP: 6.4312, 6.45]) and solve the predicament posed above. Regardless of how fate may unfold and whether it coincides with our phenomenal will or not, we are able to live in harmony with the world by seeing it sub specie aeterni and, therefore, recognizing that there is no value in the world nor a logical necessitating relation between the phenomenal will and the world (cf. [NB 30.7.16]). In viewing the world correctly and living in harmony with whatever the outcome of fate may be, we alter the limits of the world so it ceases to be the origin of ethical conflict, frustration and unhappiness, and becomes an unconditionally happy world. Namely, whatever we decide to do, there is no reason for us to be ethically distraught if the world does not accord to our wishes and desires, given that whatever happens in the world is valueless and out of our necessary control. ${ }^{18}$ (I believe this exemplifies how facts 'contribute only to setting the [ethical] problem, not to its solution' [TLP: 6.4321]. 'The facts do not belong to the performance of the ethical task [...] because that task is precisely to apprehend and accept the facts as facts' [Mulhall, 2007, 238].)

"Whoever realizes this will not want to give his body or the human body a preferred place in the world" [NB 9.11.16]. No part of the world is privileged over another. There is no need to live at war with the world in order to bend its happenings and achieve happiness. Ethical happiness is not found in our ability to control fate and necessitate the occurrence of certain valueless facts. Conversely, it is found in the good exercise of the ethical will. Namely, living in ethical harmony with the world by viewing the world sub specie aeterni and altering its limits to make it an unconditionally happy world - without the need to effect any change in the world (cf. [TLP: 6.43]). Our life, then, becomes a happy life - since the world and life are one (cf. [TLP: 5.621]).

Meanwhile, the bad exercise of the ethical will involves an inability to view the world sub specie aeterni and situate ourselves outside space and time (cf. [TLP: $6.4312,6.45]) .{ }^{19}$ We look for ethical happiness in the occurrence of certain facts,

\footnotetext{
${ }^{18}$ See [Hacker, 1986; Morris, 2008; Tejedor, 2013] for a discussion on the parallelisms between Wittgenstein's and Schopenhauer's ethics. Relatedly, Wittgenstein's work is also reminiscent of Spinoza's ethics, from whom he takes the notion sub specie aeterni (Churchill, [2009] is one of the few interpreters that acknowledges this connection).

${ }^{19}$ Wittgenstein, in his Notebooks, offered a similar distinction between our usual way of looking at things and the view sub specie aeterni. 'The usual way of looking at things sees objects as it were from the midst
} 
which we regard as ethically valuable. When fate does not accord to our plans, we are unable to live in ethical harmony with the world and we set out to change it in order to satisfy our wishes and desires, and attain those facts we perceive as valuable - thus living at war with the world.

The issue here is neither that reality does not obey our phenomenal will nor our readiness and eagerness to act and change the world, since these are just valueless facts (see Sect. 4.3). Instead, it is our inability to live in harmony with the world as a consequence of not seeing it sub specie aeterni and, therefore, failing to recognize that there is no value in the world and that there is no logical necessitating relation between the phenomenal will and the world. In viewing the world incorrectly, we mistakenly assume that some facts are more valuable that and preferred over others and, on the other hand, we develop a false sense of ethical responsibility for the occurrence of certain facts instead of others. Consequently, we face ethical punishment: we live at odds with the world, and it becomes an unhappy world. Likewise, our life becomes an unhappy life, since the world and life are one (cf. [TLP, 5.621]). ${ }^{20}$

Our unhappiness, then, is not a consequence of reality not obeying our will, but rather of our inability to view the world correctly. As Wittgenstein explains in his private correspondence:

If I am unhappy and know that my unhappiness reflects a gross discrepancy between myself and life as it is, I have solved nothing... so long as I have not achieved the supreme and crucial insight that that discrepancy is not the fault of life as it is, but of myself as I am. [Engelman, 1967, 76-77]

\subsection{Some Misconceptions About the Ethical Will}

Before exploring the problem of the meaning of life and how its solution contributes to living a good ethical life, I want to briefly discuss some misconceptions about the ethical will which may help better understand Wittgenstein's early conception of ethics and the good ethical life.

Some Wittgenstein scholars (see e.g., [Worthington, 1981, 483; Thomas, 1999, 197; Hughes, 2009, 56-57]) have suggested that the good exercise of the ethical will involves accepting that we cannot change the world and that we only become involved in unhappiness when we wish things were otherwise. ${ }^{21}$ Accordingly, they

of them, and the view sub specie aeternitatis from outside' [NB: 7.10.16]. Despite the variations in his wording, the general idea seems to be shared in both works. Wittgenstein also alludes to a similar distinction when he explains 'that the scientific way of looking at a fact is not the way to look at it as a miracle' [LOE: 11].

20 'Even if everything that we want were to happen, this would still only be, so to speak, a grace of fate' [NB, 5.7.16], i.e., something accidental. Accordingly, it cannot result in a genuinely happy, meaningful, and valuable world (and life) (see note 28). As explained in Sect. 2, the meaning, and value of the world (and life) must be necessary and non-accidental [TLP, 6.4-6.421]. 'If there is any value that does have value, it must lie outside the whole sphere of what happens and is the case. For all that happens and is the case is accidental. What makes it non-accidental cannot lie within the world, since if it did it would itself be accidental' [TLP, 6.41]. So, any ethical value which were itself accidental would be of no ethical value [TLP, 6.41].

${ }^{21}$ In Sect. 4.2 I opted in favor of speaking about living in harmony with the world, instead of speaking about acceptance. The reason for this decision is twofold. First, Wittgenstein never spoke about the idea of 
claim that the good exercise of the ethical will requires us to renounce influence on the world: we must accept that we cannot change the world.

However, the good exercise of the ethical will cannot show itself in the world through the subject's renunciation to act. Letting the world run its course or, conversely, interfering with the happenings of the world is neither ethically good nor ethically bad. Both our renunciation to act and our eagerness to act are facts that occur in the world and, thereby, are ethically valueless. ${ }^{22}$ Living in harmony with the world does not entail (or require) acting in a certain way or renouncing to act.

The good exercise of the ethical will amounts to seeing that facts, which are seen together with space and time (not in space and time), are valueless and, on the other hand, 'that whatever the one does, reality does not obey one's will, and that one must accept the outcome, whatever it may be' [Kuusela, 2018, 49]. ${ }^{23}$ There is no problem in physically and mentally acting in a certain way as long as we are able to live in harmony with the world by viewing it correctly. Against Richter [2002, 335], there is no contradiction between Wittgenstein's ethics and his non-stoic way of living (e.g., his involvement in the First World War). Living in harmony with whatever fate may bring does not entail a renunciation to act. The ethical will only alters the limits of the world, not the facts [TLP: 6.43].

This inadequate interpretation of the ethical will points to a deeper issue in the exegesis of Wittgenstein's Tractarian ethics. Many Wittgenstein scholars (e.g., [McGuinness, 2002, 157; Richter, 2002, 335; Morris, 2008, 328]) take the good and bad exercise of the ethical will as involving a certain change in the world. For instance, McGuinness [2002, 157] explains that, according to Wittgenstein, the good exercise of the ethical will does not allow a man to promote his own ethical happiness at the cost of another's life. However, Wittgenstein's remarks do not warrant such conclusion. The good and bad exercise of the ethical will cannot alter the facts in the world [TLP: 6.43]. These interpreters fail to spell out the consequences of Wittgenstein's fact-value distinction and, therefore, wrongly assume that Wittgenstein's ethics has implications for our actions and conduct in the world.

Another example is found in the work of Cavalier [1980, 159-160, 165-166, 173-175, 184, 187-195], Edwards [1982, 26, 46-47, 57, 67-68], Churchill [2009, 113-114, 121-123], Hughes [2009, 52, 56-58, 60] and Appelqvist [2013, 47-49, $51,53]$. As explained in 2.1 , they defend that the correct ethical attitude is living in

\footnotetext{
'acceptance' in any of his early work on ethics. Meanwhile, we do find some textual evidence supporting the idea of a harmonious life in the Notebooks (cf. NB, 30.7.16). Second, speaking about acceptance may lead to some of the issues described in Sect. 3, insofar as it can be understood as a certain attitude (i.e., a mental state or a state of mind) that can be described with senseful propositions.

${ }^{22}$ Furthermore, physical and mental actions are motivated by accidental purposes and motives contingent on personal inclinations (cf. [LOE: 6-7]). Only ethical actions (e.g., the good and bad exercise of the ethical will), which are not facts in the world, are motivated by genuine ethical value.

${ }^{23}$ Kuusela's arguments to support this claim differ from the ones I have offered. He rejects the idea of renunciation on the basis that not phenomenally willing anything at all is morally questionable 'insofar as it may lead, for example, to a passive acceptance of injustices' [Kuusela, 2018, 49]. I believe this argument is problematic as it runs against Wittgenstein's fact-value distinction. It suggests that one must phenomenally will such-and-such in order to be ethically good. Hence, the mark of ethical goodness and ethical badness is physical mark. Certain facts (e.g., phenomenally willing something) are deemed more ethically valuable than others (e.g., not phenomenally willing anything).
} 
acceptance and agreement with the world by adopting the alien will (i.e., God's will) on which we appear dependent.

Leaving aside the fact that Wittgenstein does not mention nor discuss God's will (see note 29) in the Tractatus, this interpretation contradicts Wittgenstein's fact-value distinction. It mistakenly claims that certain facts, such as aligning our phenomenal will with the alien will on which we appear dependent, are more valuable than others, such as failing to do so. The mark of ethical goodness and ethical badness is mistakenly conceived as a physical mark in the world.

Furthermore, this interpretation fails to abide by Wittgenstein's distinction between the phenomenal will and the ethical will. On the one hand, it mistakenly suggests that the good exercise of the ethical will demands a certain change in the phenomenal will-despite it being of interest only to psychology, and not ethics. On the other hand, it fails to realize that the ethical will can only alter the limits of the world, not the facts [TLP: 6.43$]$.

\subsection{The Meaning of Life}

Having examined Wittgenstein's understanding of the ethical will, we can now explore the problem of the meaning of life and how its solution contributes to living a good ethical life. ${ }^{24}$ According to a common view (e.g., [Cavalier, 1980, 199; Mulhall, 2007, 240-24; Morris, 2008; 328-329]), we are able to live meaningful life by dissolving the problem of life and, thereby, simply living life itself.

This common view mainly relies on Wittgenstein's discussion of the problem of life and its solution in propositions 6.5-6.522. There he explains that if an answer cannot be put into words, neither can the question and, therefore, the problem ceases to exist (cf. [TLP: 6.5, 6.521]). The problem is a pseudo-problem. Thus, a meaningful life is one that is not troubled or tormented by this pseudo-problem and does not view life as ethically problematic.

I believe it is mistaken to claim that a meaningful life amounts to dissolving the problem of life and, thereby, simply living life itself. On the one hand, the vanishing of the problem of life cannot be the sole requirement for a meaningful life. If this were the case, it would be possible to live a meaningful life despite having an incorrect ethical view of the world, a bad exercise of the ethical will and being ethically unhappy, as long as we made the problem vanish. This conclusion seems unacceptable.

On the other hand, there is no evidence in the $6.5 \mathrm{~s}$ to substantiate the claim made by this common view. In the $6.5 \mathrm{~s}$ Wittgenstein presents a method to (dis)solve pseudo-problems (cf. [TLP: 6.5]) and then sets out to exemplify how this method can be applied to tackle various philosophical problems. In 6.51 he focuses on the problem of scepticism, in 6.52 he focuses on the problem of life-understood as a philosophical problem (cf. [Christensen, 2011, 799-800]) —and, finally, in 6.53 he focuses on philosophical and metaphysical problems in general, prompting him to describe the only strictly correct method of philosophy.

\footnotetext{
${ }^{24}$ It should be noted that Wittgenstein uses de notions 'value', 'sense' and 'meaning' indistinctly in ethics (see [Fairhurst 2021a] for a defense).
} 
Wittgenstein's explanation of the (dis)solution of the problem of life in 6.52-6.522 teaches us that this problem and its solution cannot be expressed in meaningful propositions. In other words, contrary to what philosophers had previously believed, philosophy cannot meaningfully speak about this problem and its solution. Conversely, it can only demonstrate that, whenever someone wanted to say something philosophical about this problem and its solution, they fail to give meaning to certain signs in their propositions and, therefore, are speaking nonsense (cf. [TLP: 6.53]).

This clarification, unfortunately, tells us nothing about the meaning of life and the world nor the difference between living a meaningful life and living a meaningless life. Wittgenstein's philosophical clarification of the problem of life in the $6.52 \mathrm{~s}$ is no more than a consequence of the fact-value distinction outlined in the $6.4 \mathrm{~s}$ and his understanding of pictures (i.e., propositions and thoughts). It should not be taken as Wittgenstein's final say on the meaning of life.

It may be countered that there is no such thing as the meaning of life and that, consequently, the (dis)solution of the problem of life allows us to live a life free from the torment that arises from this ethical pseudo-problem. However, this seems to directly conflict with Wittgenstein's remarks in 6.41. Wittgenstein explains that 'there are, indeed, things that cannot be put into words. They make themselves manifest. They are what is mystical' [TLP: 6.522]. I believe the meaning of life far from being an exception, constitutes a clear-cut example. Wittgenstein, in 6.41, affirms that the meaning or 'sense of the world [and life] must lie outside of the world' ([TLP: 6.41], my brackets) ${ }^{25}$, outside of that which can be put into words: in the mystical. The point of Wittgenstein's dis(solution) of the problem of life is to help us avoid searching for the meaning of life in the world and direct us to the mystical, as it is only outside of the world where we will find the meaning (or sense) of life and the world (see [Atkinson, 2009] for a study of the mystical).

In 6.41 and 6.4312 Wittgenstein explains that immortality is often introduced in hopes of solving the riddle of life. Wittgenstein contends, however, that even if there was a guarantee of the temporal immortality of the human soul, our eternal survival after death does not provide a solution to the riddle. Conversely, it just makes the riddle eternal. 'The solution of the riddle of life in space and time lies outside space and time' [TLP: 6.4312]. Namely, 'the sense of the world must lie outside of the world' [TLP: 6.41 — the meaning of life and the world are one and the same, since 'the world and life are one' [TLP: 5.621].

Thomas [1999, 196-197] and Worthington [1981, 486] discuss these propositions in relation to NB 6.7.16. They claim that we overcome the problem of life by living in eternity and, thereby, renouncing influence on the world by adopting the alien will on which we appear dependent. However, this interpretation is inadequate in so far as it claims that the mark of ethical goodness is a physical mark in the world (see Sect. 3.1, 4.2 and 4.3). Furthermore, against 6.4312 and 6.52-6.522, Thomas and Worthington claim that the solution to the riddle of life lies in space and time.

\footnotetext{
${ }^{25}$ Given that Wittgenstein often uses meaning and sense interchangeably when speaking about ethics (see footnote 24) and, on the other hand, that he identifies the world with life in 5.621 ('The world and life are one'), I believe it is reasonable conclude that 6.41 includes the affirmation of the meaning of life.
} 
Specifically, it lies in our ability to renounce influence on the world and align our phenomenal will with the alien will on which we appear dependent.

The meaning of life and the world, on the contrary, is to be found in the mystical view that allows us to see the world from outside space and time as something meaningful: the view of the world sub specie aeterni (cf. [TLP: 6.4312, 6.45]). ${ }^{26}$ Viewing the world sub specie aeterni from outside space and time allows us to see that there is no value in the world (cf. [TLP: 6.41, 6.4312, 6.52-6.522]). Thus, there is no point in endlessly searching for the meaning of life and the world in valueless and accidental facts. Conversely, we must alter the limits of the world to make it altogether different, without effecting any change in the world.

As explained in Sect. 4.2, viewing the world sub specie aeterni alters the limits of the world so it ceases to be the source of ethical conflict and becomes an unconditionally happy world. In doing so, we are able to recognize that it is this unconditionally happy world as a whole that is meaningful and valuable, not a particular instance of it (e.g., the occurrence of one fact instead of another). 'It is not how things are in the world that is mystical, but that it exists' [TLP 6.44].

Regardless of what may happen in the world, the world and life as a whole remain unconditionally happy and, by extension, valuable and meaningful when seen correctly (i.e., sub specie aeterni). ${ }^{27}$ In other words, giving sense and meaning to our life (and the world) is accomplished through a good exercise of the ethical will and, in consequence, seeing the world sub specie aeterni, as a limited whole, as something valuable and meaningful-without altering the facts in the world. A happy world is an ethically and valuable world and a happy life is an ethically meaningful and valuable life: a good ethical life.

Meanwhile, the bad exercise of the ethical will leads to an unhappy world and an unhappy life because of our inability to see the world sub specie aeterni and alter its limits correctly. As a consequence of not viewing the world as a whole from outside space and time, we are unable to see that there is no value in the world (cf. [TLP: $6.41,6.4312,6.52-6.522]$ ). Thus, we endlessly search for the meaning of life and the world in accidental, valueless and meaningless facts, but to no avail. This pointless search for the meaning of life and the world in space and time leads to a life at war with the world (see Sect. 4.2). The world and life, therefore, become altogether unhappy and, by extension, meaningless and valueless, without effecting any change

\footnotetext{
${ }^{26}$ Appelqvist [2013, 206-207] discusses this idea in relation to religion and God. She explains that it is through a mystical experience that we are able live in harmony with reality and solve the problem of life. This experience is not only ethical but also religious: it involves a belief in God (cf. [NB: 11.6.16, 8.7.16]). 'To believe in God is to see one's life as meaningful in spite of its factual meaningless' [Appelqvist, 2013, 206]. Unfortunately, there is insufficient evidence in the Tractatus to claim that God plays a primordial role in Wittgenstein's ethics the good ethical life (see note 29).

27 This mystical view of the world outside space and time may allow us to explain the connection between ethics and aesthetics in 6.421. It could be argued that the view of the world sub specie aeterni transforms the limits of the world so it becomes both an ethically and aesthetically meaningful and valuable world. Wittgenstein explains something along these lines in the Notebooks when he claims that 'the work of art is the object seen sub specie aeternitatis; and the good life is the world seen sub specie aeternitatis. This is the connexion between art and ethics' [NB: 7.10.16]. Notwithstanding, examining this issue in detail exceeds the scope of this paper and requires a separate investigation.
} 
in the world. We are unable to live a good ethical life because of not viewing the world correctly.

\section{Conclusions}

Summarizing, the good ethical life is predicated on a good exercise of the ethical will and solving the riddle of life, both of which demand viewing the world sub specie aeterni in order to make the world (and life) a happy, meaningful and valuable world (and life). Meanwhile, the bad ethical life is predicated on a bad exercise of the ethical will and an inability to solve the riddle of life as a consequence of not viewing the sub specie aeterni, thus leading to a unhappy, meaningless and valueless world and life.

The difference between the good ethical life and a bad ethical life is not to be found in the facts in the world, but rather in our ability or inability to have a correct ethical view of the world and alter the limits of the world to make it altogether different. For instance, two individuals could live the same life, have the same mental states and face exactly the same happenings, and act in the same way throughout their life. However, as a consequence of having either the correct or incorrect ethical view of the world, one of them sees the world as a happy one and the other as an unhappy one.

The lack of a physical mark in the world to distinguish between the good ethical life and the bad ethical life means that we are unable to recognize if other ethical subjects have a correct ethical view of the world and vice versa-i.e., they are unable to recognize if we have a correct ethical view of the world. Furthermore, the ethical reward and ethical punishment that is internal to ethical actions also lacks a physical mark in the world. Ethical happiness and ethical unhappiness are not describable psychological or mental states. ${ }^{28}$ That is why it is the world and life as a whole that is happy or unhappy, and not a particular instance of it (cf. [TLP: 6.43]).

However, given that the good ethical life does not result in physical reward (e.g., feeling happiness or joy) nor is it externally recognizable, what is the point of being ethically good and living a good ethical life? First, being recognized by others as ethically good or bad is unimportant for Wittgenstein. Ethics is a matter of personal ethical responsibility. There is no room for external recognition or validation.

Second, physical reward and physical punishment are accidental facts in the world that are dependent on fate. There is no ethical reason in favour of striving for facts that are valueless, beyond our control and could have easily been otherwise.

\footnotetext{
${ }^{28}$ Happiness is ordinarily defined as a psychological mental state. For instance, I may feel happy at a particular point and time because it is sunny, I passed my exam, I saw my best friend and so on. However, this kind of happiness is a valueless fact in the world, which is fleeting and accidental. As explained previously (see Sect. 2), there is no ethical reason in favor of striving for certain facts, such as happiness or any other mental state, because they are ethically valueless, beyond our control, and could have easily been otherwise. Meanwhile, ethical happiness is non-accidental, absolute, permanent, and necessary: it is unconditional happiness. Hence ethical happiness cannot be a mental state in the world since if it existed in the world, it would itself be accidental and, thereby, be of no ethical value.
} 
Finally, and most importantly, there is no rational justification or explanation regarding why we should be ethically good and live a good ethical life - and if there were we could not put it into words, given that propositions 'can express nothing that is higher' ([TLP: 6.42]). ${ }^{29}$ The reasons in favour of being ethically good and living a good ethical life are to be ethically good and live a good ethical life. The value of being ethically good and living a good ethical life is self-evident: it admits no justification or explanation (cf. [TLP: 6.4, 6.41]). As Wittgenstein later explained: being ethically good is the absolute right road, 'the road which everybody on seeing it would, with logical necessity, have to go, or be ashamed for not going' [LOE: 7].

Acknowledgements This work was supported by the Ministerio de Educación, Cultura y Deporte del Gobierno de España (MINECO) under Grant FPU16/05569. Thanks to Janet Anne Chilton and Dr. Kuusela for numerous comments on previous versions of this paper.

Funding and/or Conflicts of Interests/Competing Interests This work was supported by the Ministerio de Educación, Cultura y Deporte del Gobierno de España (MECD) under Grant FPU16/05569.

Open Access This article is licensed under a Creative Commons Attribution 4.0 International License, which permits use, sharing, adaptation, distribution and reproduction in any medium or format, as long as you give appropriate credit to the original author(s) and the source, provide a link to the Creative Commons licence, and indicate if changes were made. The images or other third party material in this article are included in the article's Creative Commons licence, unless indicated otherwise in a credit line to the material. If material is not included in the article's Creative Commons licence and your intended use is not permitted by statutory regulation or exceeds the permitted use, you will need to obtain permission directly from the copyright holder. To view a copy of this licence, visit http:/creativecommons.org/ licenses/by/4.0/.

\footnotetext{
${ }^{29}$ Wittgenstein makes a similar point when discussing theological ethics with Schlick. According to Schlick there 'used to be two conceptions of the essence of the good: according to the shallower interpretation the good is good because it is what God wants; according to the profounder interpretation God wants the good because it is good' [Waissman, 1979, 115]. Wittgenstein countered that it is actually the first interpretation that is profounder since 'it cuts off the way to any explanation 'why' it is good [...]. The first conception says clearly that the essence of the good has nothing to do with facts and hence cannot be explained by any proposition' [Waissman, 1979, 115]. Throughout this discussion, Wittgenstein endorses his earlier remarks from the Notbeooks regarding God and ethics. He explains that 'if there is any proposition expressing precisely what I think, it is the proposition "What God commands, that is good"' ([Waissman, 1979, 115] cf. [Waissman, 1979, 118]) - he offers a similar remark in Culture and Value [Wittgenstein 1998]: 'what is Good is Divine too. That, strangely enough, sums up my ethics' [CV 4/MS 107192 c: 10.11.1929]. Lovibond, Hughes, Churchill, Richter and Appelqvist resorted to the Notebooks to explain the connection between God and ethics in the Tractatus. However, despite his earlier and later remarks on the connection between God and ethics, Wittgenstein explicitly avoided employing these remarks in the Tractatus, thus suggesting that the connection between God and ethics is no longer endorsed in these works. At most we find a reference to God in the Prototractatus, where Wittgenstein initially included the following remark to proposition 6.4412: 'Wie sich alles verhält, ist Gott. Gott ist, wie sich alles verhält' [MS 104, 84]. However, it leaves out the connection between God and ethics. Further arguments are required to substantiate the claim that Wittgenstein maintains this connection between God and ethics in the Tractatus.
} 


\section{References}

Appelqvist, H. (2013). Why does Wittgenstein say that ethics and aesthetics are one and the same?. In P. Sullivan, \& M. Porter (Eds.), Wittgenstein's Tractatus: History and Interpretation (pp. 40-58). Oxford: Oxford University Press

Atkinson, J. R. (2009). The Mystical in Wittgenstein's Early Writings, Routledge: New York

Cahill, K. M. (2004). Ethics and the "Tractatus": A Resolute Failure. Philosophy, 79(307): 33-55.

Cahill, K. M. (2011). The Fate of Wonder. New York: Columbia University Press

Cavalier, R. J. (1980). Ludwig Wittgenstein's Tractatus Logico-Philosophicus: A Transcendental Critique of Ethics. Washington: University Press of America

Christensen, A. S. (2011). Wittgenstein and Ethics. In M. McGinn, \& O. Kuusela (Eds.), The Oxford Handbook of Wittgenstein (pp. 796-818). Oxford: Oxford University Press

Churchill, J. (2009). The Convergence of God, the Self, and the World in Wittgenstein's Tractatus' in. In U. Arnswald (Ed.), Search of Meaning: Ludwig Wittgenstein on Ethics, Mysticism and Religion (pp. 113-130). Karlsruhe: KIT Scientific Publishing

Diamond, C. (2000). Ethics, Imagination and the Attractions of Wittgenstein's Tractatus. The New Wittgenstein, ed. Alice Crary and Rupert Read (pp. 149-173). London: Routledge

Edwards, J. C. (1982). Ethics Without Philosophy: Wittgenstein and the Moral Life. Florida: University Presses of Florida

Engelman, P. (1967). Letters from Ludwig Wittgenstein with a Memoir. Oxford: Blackwell

Fairhurst, J. (2019). The Ethical Subject and the Willing Subject in the Tractatus: an Alternative to the Transcendental Reading. Philosophia, 47(1), 75-95

Fairhurst, J. (2021a). The Ethical Significance of the Tractatus Logico-Philosophicus. Teorema, 40(2), $151-168$

Fairhurst, J. (2021b). Wittgenstein, deflationism and moral entities. Synthese, 199, 11023-11050

Hacker, P. M. S. (1986). Insight and illusion themes in the philosophy of Wittgenstein. Oxford: Oxford University Press

Harcourt, E. (Forthcoming). Wittgenstein, Ethics and Therapy. In C. Jäger, \& W. Löffler (Eds.), Epistemology: Contexts, Values, Disagreement, Proceedings of the 34th International Wittgenstein Symposium. Frankfurt: Ontos

Hughes, L. (2009). 'If there is any value that does have value, it must lie outside the whole sphere of what happens and is the case (TLP 6.41)'. In U. Arnswald (Ed.), In Search of Meaning: Ludwig Wittgenstein on Ethics, Mysticism and Religion (pp. 51-66). Karlsruhe: KIT Scientific Publishing

John, P. C. (1988). Wittgenstein's 'Wonderful Life'. Journal of the History of Ideas, 49(3), 495-510

Kelly, J. C. (1995). Wittgenstein, the Self, and Ethics. The Review of Metaphysics, 48(3), 567-590

Klagge, J. C. (2011). Wittgenstein in Exile. London: MIT Press

Kremmer, M. (2001). The Purpose of Tractarian Nonsense. Nous, 35(1), 39-73

Kuusela, O. (2018). Wittgenstein, Ethics and Philosophical Clarification. In R. Agam-Segal, \& E. Dain (Eds.), Wittgenstein's Moral Thought (pp. 37-66). New York: Routledge

Kuusela, O. (Forthcoming). Later Wittgenstein on moral good: realism without the postulation of moral properties or naturalistic reduction. S. Grevered Culture and Value after Wittgenstein. Oxford: Oxford University Press

McGuinness, B. (2002). Approaches to Wittgenstein: Collected Papers. London: Routledge

Morris, M. (2008). The Routledge Philosophy Guidebook To Wittgenstein and the Tractatus. London: Routledge

Mulhall, S. (2007). Words, Waxing and Waning: Ethics in/and/of the Tractatus Logico- Philosophicus'. In G. Kahane (Ed.), Wittgenstein and His Interpreters (pp. 221-247). Edward Kanterian and Oskari Kuusela, Oxford: Blackwell Publishing

Richter, D. (1996). Nothing to be Said: Wittgenstein and Wittgensteinian Ethics. Southern Journal of Philosophy, 34(2), 243-256

Richter, D. (2002). 'Whose Ethics? Which Wittgenstein?'. Philosophical Papers, 31(3), 323-342

Richter, D. (2018). Sketches of Blurred Landscapes: Wittgenstein and Ethics. In R. Agam-Segal, \& E. Dain (Eds.), Wittgenstein's Moral Thought (pp. 153-173). New York: Routledge

Rudebush, T., \& Berg, W. M. (1979). 'On Wittgenstein and Ethics: A Reply to Levi.' Télos, 40, 150-160

Teichmann, R. (2015). Wittgenstein on Thought and Will. London: Routledge

Tejedor, C. (2013). 'The Earlier Wittgenstein on the Notion of Religious Attitude.' Philosophy, 88(1), $55-79$ 
Thomas, E. V. (1999). From Detachment to Immersion: Wittgenstein and 'The Problem of Life'. Ratio, 12(2), 195-209

Waissman, F. (1979). Wittgenstein and the Vienna Circle. Oxford: Basil Blackwell

Wittgenstein, L. (1965). A Lecture on Ethics. The Philosophical Review, 74(1), 3-12. [LOE]

Wittgenstein, L. (1991). Geheime Tagebücher: 1914-1916. Vienna: Verlag Turia \& Kant. [GT]

Wittgenstein, L. (1997). Prototractatus. London: Routledge

Wittgenstein, L. (1998). Culture and Value. Oxford: Blackwell. [CV]

Wittgenstein, L. (2001). Tractatus Logico-Philosophicus. London: Routledge. [TLP]

Wittgenstein, L. (2000). Wittgenstein's Nachlass: The Bergen Electronic Edition. Oxford: Oxford University Press. [MS] (References by manuscript/typescript number)

Wittgenstein, L. (2015). Notebooks 1914-1916. London: Forgotten Books. [NB]

Worthington, B. A. (1981). Ethics and the Limits of Language in Wittgenstein's Tractatus. Journal of the History of Philosophy, 19(4), 481-496

Publisher's Note Springer Nature remains neutral with regard to jurisdictional claims in published maps and institutional affiliations. 